\title{
Representações sociais de jornalistas argentinos e brasileiros sobre Maradona e Romário
}

\author{
Esteban Manuel Barcelona* \\ Sebastião Josué Votre ${ }^{* *}$ \\ Nilda Ferreira Teves ${ }^{* * *}$ \\ Carlos Henrique de Vasconcellos Ribeiro ${ }^{* * * *}$
}

\begin{abstract}
Resumo: Este artigo analisa representações sociais de jornalistas argentinos e brasileiros sobre Maradona e Romário, em matérias publicadas após o jogo em homenagem ao primeiro e após o milésimo gol do segundo. O corpus argentino de análise é constituído por 12 notícias de diferentes mídias impressas, relacionadas ao evento. $\mathrm{O}$ brasileiro, de 34 notícias da mesma natureza. A análise das notícias resultou em cinco categorias de consenso sobre os homenageados: origem social, desempenho profissional, características pessoais, vínculo com os torcedores e transcendência. Os dissensos estão associados a fatos pontuais, na carreira de cada um deles. A análise do conteúdo das representações sobre Maradona permite associá-lo ao gaúcho argentino Martín Fierro. Quanto a Romário, sobressai o mulato de Gilberto Freyre, que passa do mucambo ao sobrado.
\end{abstract}

Palavras-chave: representações sociais, consensos, dissensos, mídia impressa.

\footnotetext{
"Professor na UNRC. Argentina. E-mail: emanubarcelona@hum.unrc.edu.ar

"Professor na UGF. Rio de Janeiro. E-mail: sebastianovotre@yahoo.com

"'Professora na UGF. Rio de Janeiro. E-mail: tevesnilda@uol.com.br

....Professor na UGF. Rio de Janeiro. E-mail: c.henriqueribeiro@ig.com.br
} 


\section{INTRODUÇão}

Segundo o jornal JOGO EXTRA (2010, p. 12) o imaginário brasileiro atribui ao argentino os traços de "um povo que gosta [...] de dramas, novelas, personagens fantásticos e futebol"1. Para este artigo, apoiamo-nos em estudos de Archetti (2003), que abriu as portas para o estudo do esporte e sua relação com o espírito nacional, quando estudou as masculinidades da cultura argentina por meio do futebol, do tango e do pólo. Constatamos que existe uma lacuna de conhecimento com respeito às aproximações e afastamentos entre os protótipos e estereótipos culturais de argentinos e brasileiros por meio das representações sociais de personagens esportivos elucidadas no tratamento de seus jornalistas.

Esta temática surgiu durante o jogo-homenagem a Maradona (10 de novembro de 2001), quando comparamos as convergências e divergências entre a imagem midiática e a imagem de sua autobiografia publicada em 2000: Yo soy el Diego de la gente (BARCELONA, 2004; 2010a). Os eventos destacam-se em superexposição midiática no caso do jogo-homenagem e no caso da autobiografia, que foi escolhida como "bíblia" pela "Igreja Maradoniana". Só na Argentina, se venderam mais de $300 \mathrm{mil}$ exemplares, apenas em espanhol, sem contar as traduções (PICABEA, 2005). Consideramos a obra como detentora do "núcleo central das representações sociais" porque, como constatamos (BARCELONA, 2004), os jornalistas ${ }^{2}$ no geral não contradizem essa "bíblia", transformando-a em meio de consulta para outras matérias jornalísticas e também para o meio acadêmico sobre a relação de Maradona com a identidade do povo argentino. Considerar-se-ia traição contradizê-la.

Optamos por proceder a uma análise similar com outro esportista, desta vez brasileiro, que possuísse uma autobiografia e/

\footnotetext{
1JOGO EXTRA. Reencontro no domingo: hermanos pegam o México nas oitavas, como em 2006, mas agora com Messi como titular, Rio de Janeiro, 23 junho. 2010, p. 12.

${ }^{2}$ Observamos (BARCELONA, 2004) que as edições especiais publicadas em homenagem são: El 10, Vida y Magia de Diego Maradona (Clarín, 2001); La vida de un genio (El Gráfico, 2001); Homenaje al más grande (Olé, 2001).
} 
ou jogo onde fosse homenageado com superexposição midiática. A escolha recaiu em Romário de Souza Faria, tendo como evento midiático o jogo do gol mil (20 de maio de 2007), interpretado como homenagem.

Selecionamos estes jogos porque fecham com "chave de ouro" a carreira dos dois jogadores, pois é nesse momento que deixam a trajetória de sucesso e entram para a história esportiva de seus países com seus percalços, dores, gols e sucesso. $\mathrm{O}$ momento propicia à mídia fazer um recorte sobre suas vidas mostrando-os dentro e fora do campo, recontando estórias conhecidas, mas que são revisitadas, com novos olhares e novas percepções.

Para comparar as representações sociais dos jornalistas sobre os dois personagens, escolhemos cinco dimensões: origem social, perfil pessoal, profissional, vínculo com o torcedor e transcendência.

Seguimos o jornalista Eduardo Galeano (2002), que foi o primeiro a juntar Maradona e Romário no livro $\mathrm{O}$ futebol a sol e sombra, em que descreve os personagens, mas sem compará-los. Com esta comparação, procuramos identificar representações sociais (MOSCOVICI, 1978), sobre Maradona e Romário e relacioná-las com características culturais de seus países. Escolhemos os clássicos Martín Fierro e Sobrados e Mucambos, de Hernández e Freyre respectivamente, como obras que nos possibilitam discutir os estereótipos nacionais. São obras de referência nos dois países e são compreendidas como parte do discurso fundador de suas culturas; analisadas no contexto histórico que foram construídas, ajudam-nos a pensar como foram produzidos na coletividade os arquétipos nacionais; fornecem indícios sobre como se consolidou a imagem típica do argentino e do brasileiro.

Este estudo se justifica por colaborar com as discussões sobre relações e tensões entre personagens esportivos, seu tratamento midiático, características nacionais e representações sociais, com cruzamentos das áreas do jornalismo esportivo, comunicação, história, literatura e sociologia do esporte. 
O estudo oportuniza a novos pesquisadores a análise de personagens-referência contemporâneos no discurso jornalístico, bem como analisar os recursos lingüísticos no tratamento midiático, com foco no que é consenso e dissenso na trajetória de figuras esportivas que ajudam a compreender a sociedade em que se inserem.

O estudo identificou características em comum entre Romário e Maradona, como baixa estatura, superexposição midiática, bateboca e brigas na mídia, autoestima alta, orgulho, origem humilde, aceitação da origem, retorno às origens, defesa das pessoas da mesma origem, títulos importantes desde as categorias de base, clamor popular, salvador da pátria, rebeldia/transgressão, conquista de Copa do Mundo, felicidade ao povo, despedidas e retornos, autobiografia e biografia midiática, estátuas, cantigas e frases populares, projetos sociais beneficentes, participação em jogos beneficentes e presença marcante no futebol e na política.

Apresentamos as estratégias metodológicas, tendo como referencia a teoria das representações sociais com foco nos estudos midiáticos e na análise dos consensos e dissensos que a mídia constrói sobre estes dois ícones do futebol.

\section{EstratÉGIAS METOdOLÓGICAS}

Esta pesquisa é comparativa, de natureza qualitativa. Para o lado argentino, constituímos um corpus de notícias jornalísticas integrado por 12 notícias de diversos jornais e de uma revista, nos dias seguintes ao do jogo-homenagem: três notícias do Clarín, três notícias do La Nación, duas notícias do Olé, duas notícias do Puntal e duas notícias da revista El Gráfico. Para o lado brasileiro, constituímos um corpus de 34 notícias, também de diferentes mídias, todas após o jogo do Gol Mil: Extra (16), O Globo (oito), Jornal dos Sports (cinco) e O lance (cinco). Os critérios utilizados para a seleção das notícias foram que as mesmas fossem posteriores aos eventos e tratassem sobre eles. Para o lado argentino selecionamos menor quantidade de noticias, por essas serem mais extensas. Sendo assim, equilibrou-se a sua quantidade sem alterar a qualidades das matérias 
selecionadas, visto que muitas das notícias descartadas tinham o conteúdo próximo das escolhidas e selecionadas para este artigo. Consideramos que alcançamos um momento de saturação empírica para o lado de Maradona, visto que os conteúdos se repetem em um quantitativo menor de material jornalístico.

Para a elaboração das categorias aplicamos a análise de conteúdo (BARDIN, 2009). Selecionamos cinco dimensões que sobressaíam na categorização prévia: origem social, perfil pessoal, perfil profissional, vínculo com o torcedor e transcendência. Para validar a técnica de identificação das categorias, utilizamos também o método do paradigma indiciário proposto por Ginzburg (1989), que favorece o uso de instrumentos de observação e escalas de investigação de tipo microscópico.

Para a edição dos dados selecionados da redação jornalística, bem como para apresentação e análise dos dados, utilizamos a técnica do Discurso do Sujeito Coletivo, de Lefebvre e Lefebvre (2007): agrupamos na terceira pessoa do singular as temáticas similares, qualificadoras de Maradona e de Romário. Com isso, produzimos um efeito de "coletividade falando" (LEFEBVRE; LEFEBVRE, 2007, p. 2), contribuindo para a identificação das representações sociais $^{3}$ dos jornalistas que assinam as notícias. Esta técnica permitiu descrever e interpretar representações sociais robustas sobre as categorias de consenso e de dissenso que identificamos.

A seguir apresentamos as representações sociais jornalísticas dos dois ex-jogadores, com vistas ao entendimento das construções de identidade efetuadas pela mídia esportiva impressa.

\section{As REPRESENTAÇÕES SOCIAIS MIDIÁTICAS}

Apresentamos aqui as representações sociais sobre os personagens dos jornalistas, divididas em categorias de consensos e dissensos e ilustramos cada categoria. Em seguida aproximamos

\footnotetext{
${ }^{3}$ Ver Barcelona (2010b) para procedimentos de coleta, descrição das mídias selecionadas e construção do corpus.
} 
essas representações a paradigmas culturais próprios de cada país, como foco na construção identitária consolidada ao longo do tempo de sua formação. Guia-nos o pressuposto de que compreender como a mídia esportiva retrata os ídolos esportivos de um povo, no esporte nacional, contribui para compreender como esse povo se autorrepresenta.

Para a análise das representações sociais dos jornalistas, apoiamo-nos no enfoque teórico de Serge Moscovici (1978, p. 41), para quem as representações sociais veiculam valores, ideias, crenças e práticas partilhadas socialmente, como entidades quase tangíveis: "elas circulam, cruzam-se e se cristalizam incessantemente através de uma fala, um gesto, um encontro".

Ao analisarmos percepções, valores e opiniões de jornalistas, encaramos o ponto de vista dos indivíduos e dos grupos tanto pelo "caráter de comunicação" como pelo "caráter de expressão": "Com efeito, as imagens, as opiniões, são comumente apresentadas, estudadas e pensadas tão-somente na medida em que traduzem a posição e a escala de valores de um indivíduo ou de uma coletividade" (MOSCOVICI, 1978, p. 49).

Para qualificar uma representação como social, não basta definir o agente que a produz; interessa mais saber por que se produz essa representação, qual é sua função. Para entender o sentido "social" de uma representação, temos que destacar a função a que este sentido corresponde no contexto em que é gerado. Uma representação "contribui exclusivamente para os processos de formação de condutas e de orientação das comunicações sociais" (MOSCOVICI, 1978, p. 77).

Nesse sentido, a identificação e análise das representações sociais que se estabelecem no tratamento que os jornalistas produzem sobre Maradona e Romário pode considerar-se uma contribuição original, visto que verificamos uma lacuna no estudo de esportistas consagrados, que permita relacionar essas representações com os mitos que expressam tipificações da identidade nacional dos países desses personagens. 
A análise e a discussão dos dados permitem postular que certas "representações sociais" particulares contribuem com características mais gerais, que ajudam a compreender melhor o modo de ser de uma sociedade e sua cultura. Permitem entender, também, que essas representações particulares não surgem aleatoriamente, mas como consequência do modo de ser de uma sociedade e de sua cultura e, portanto, do modo de perceber e conceber dos seus protagonistas no caso deste estudo, dos jornalistas. Assim, por exemplo, podemos compreender a razão por que os jornalistas argentinos descrevem Maradona com relativo consenso, numa sociedade que se considera fundada no dissenso, enquanto os jornalistas brasileiros descrevem Romário de forma menos consensual, numa sociedade em que, supostamente, predominariam os consensos (LOVISOLO, 2000). A seguir, apresentamos os consensos e dissensos depreendidos das análises sobre as matérias da mídia desses dois países sobre Maradona e Romário.

\section{REPRESENTAÇÕES SOCIAS MIDIÁTICAS ARGENTINAS SOBRE Maradona}

Apresentamos a seguir as representações sociais depreendidas da análise das reportagens sobre Maradona, nas cinco dimensões que desdobram as dimensões pessoal e profissional (BARCELONA, 2003).

Comecemos pelos consensos dos jornalistas, nas dimensões que abordam questões relativas a: i) Origem social; ii) Aspectos profissionais; iii) Aspectos pessoais; iv) Vínculo com o torcedor; e v) Transcendência. Alguns indícios se repetem, porque não são incompatíveis e as suas categorias se inter-relacionam. Nessas representações, distinguimos consensos e dissensos, levando em conta o modo como os jornalistas se posicionam frente aos temas noticiados através de seus discursos. 
Entre os consensos, sobressarem as representações vinculadas à sua condição de pibe ${ }^{4}$ humilde que, por ser predestinado, gênio e artista, conquistou o coração de seu povo, sustentando-se no seu orgulho, rebeldia, lealdade e solidariedade, preocupado em oferecer alegria e felicidade à sua torcida, que o reconhece, honra e o considera um salvador da pátria, excepcional, inquestionável, transcendendo para o sacro, o sobrenatural, eterno, imortal (BARCELONA, 2003), traços que constituem uma síntese do personagem.

Por outro lado, o primeiro dissenso dos jornalistas vincula-se com a transcendência; os jornalistas exacerbam o sensacionalismo, mas não entram em consenso sobre como esse traço pode aumentar a transcendência. $\mathrm{O}$ fato de existirem poucos dissensos sobre Maradona pode ser explicado em parte pela representação de "inquestionável", a ele imputada, por seu papel na conquista da Copa do Mundo de 1986.

Essa transcendência, na ótica que valoriza o sagrado, mostra antecedentes em outros personagens que estão presentes na memória nacional argentina. Em Martín Fierro, o personagem principal, caracterizado por sua pobreza e, ao mesmo tempo, por seu orgulho e talento rebelde e pícaro, habilidoso e preocupado com as possíveis chances de seu retorno à civilização e às normas, permite estreita associação com este ídolo do esporte. Esta aproximação entre os dois personagens precisa de novos aprofundamentos, uma vez que, pode-se argumentar, Maradona é um herói urbano, enquanto Martin Fierro é rural.

Constatamos que a análise de conteúdo, a exploração das representações e as discussões focadas nas narrativas populares são caminhos válidos e auspiciosos para sintetizar tentativas de compreensões, talvez um pouco ambiciosas, mas, ao mesmo tempo,

${ }^{4}$ Pibe corresponde a moleque. Archetti (2003a, p. 245) o analisa no capitulo "Maradona: la saga del pibe de oro" e em El potrero y el pibe: territorio y pertenencia en el imaginario argentino (2008). 
necessárias para se entender o modo como nossos arquétipos atuais projetam-se numa cultura cujas bases são ressignificadas ao longo do tempo.

A categoria Salvador da pátria sintetiza uma representação reincidente e relacionável com a vitória da guerra simbólica (ELIAS; DUNNING: 1992) contra os ingleses. Maradona pode ser comparado com o pai da pátria, o libertador General José de San Martín, que participou do processo da independência hispano-americana a partir de 1814, na Argentina, Chile e Peru. Por isso, é considerado o "libertador" da América do Sul, juntamente com Simón Bolívar.

Os jornalistas destacam as representações sociais de lealdadefidelidade, (em dez das doze notícias), e religiosidade/transcendência, temática recorrente, que aparece em todas as notícias.

No imaginário antigo e medieval, os heróis míticos e cavalheirescos são personagens que demonstram com suas práticas uma condição de excepcionalidade, em virtude do nascimento, do bem do valor e da força (DINI; NICOLAUS, 2001, p. 63). Nós relacionamos o pibe Maradona com Peter Pan, com o herói cavalheiresco montado em seu cavalo, com os personagens de San Martín, Robin Hood e Martín Fierro. Na edição da última homenagem de Olé, encontra-se uma caricatura de Maradona como personagem sagrado, montado em um cavalo empinado sobre duas patas com uma bola na altura da testa (FARINELLA, 2008: p. 121).

Como estratégia de ilustração do que acabamos de expor, editamos representações com categorias de consenso e de dissenso. A síntese da edição que se segue tem formato denso, para construir a impressão de jornalistas interagindo ao vivo, como se falassem em sessão coletiva. Com respeito aos consensos, apresentamos a representação vinculada com a origem social. Humildade de origem, "Villa Fiorito"5. Nesta dimensão, Maradona é descrito como pobre, favelado, surgido de uma comunidade carente como a "favela" Villa Fiorito, no Bairro de Lanús, na periferia pobre de Buenos Aires. Em

${ }^{5}$ Villa remete a comunidade extremamente pobre ou favela, e villero a favelado. 
que todos os indícios se relacionam com a pobreza e com as dificuldades de origem e ascensão social:

"adicto y genial, villero y genial, bostero y genial [...]. Porque su origen humilde bastó muchas veces para ser descalificado en un país insistentemente sectário (3); también quedó más de una vez cara a cara con el que nunca quiso ser cuando soñaba en Villa Fiorito y en sus comienzos en Argentinos (8); El pibe de la Villa Fiorito que llegó a la cima del planeta, por su amor a la pelota (11); como si este Riquelme se hubiese nutrido de aquel Diego de las canchas poceadas de Villa Fiorito [...]. Aqui y allá. En Villa Fiorito y en Nápoles [...]. Con la pelota, el hombre parece más fiel a sus orígenes (12)."

Passemos agora à análise dos dissensos dos jornalistas, em que se apresentam perspectivas e opiniões discordantes; o discurso jornalístico se concentra apenas na dimensão transcendência. Já não se trata de questões vinculadas a Maradona em sua origem social, profissional ou pessoal, sobre seu vínculo com os torcedores ou sobre aceitar sua transcendência. Até este ponto, as opiniões quase não variam. Mesmo assim, quando os temas noticiados não dependem apenas de Maradona, mas envolvem a terceiros que interpretam ou opinam, a questão muda. Já não é apenas o ídolo que se observa, mas também a opinião do próprio observador.

Distribuímos os dissensos em quatro representações: a denominação do jogo-homenagem; a opinião sobre aposentar a camisa 10; a opinião sobre Maradona continuar jogando futebol profissionalmente e o número de torcedores no jogo-homenagem. Vejamos a ilustração sobre como chamar o jogo:

"se asocian al tributo [...]. La peregrinación hacia la Bombonera no sabe de despedidas. Sólo busca venerarlo (5); Homenaje, fierita, homenaje", e comenta que "Quien osara utilizar la palabra despedida estaba frito [...]. 'Del fútbol no me voy a ir nunca'. Entonces empezó la batalla semántica. Debían grabarse a fuego la palabra homenaje [...], si 
se hablaba de despedida estarían cometiendo un acto de alta traición (6); Diego podría retirarse desde cualquier sitio. Podrían homenajearlo desde cualquier lugar (8); Las más nobles emociones en el agasajo a Maradona [...]. Su partido despedida tocó hondo en su corazón y en el de la gente [...], con una multitud que lo elevó al altar y le rindió culto tribunero al ídolo en su despedida de las canchas [...]. El partido que combinó el agasajo y la despedida cumplió la naturaleza para que fue concebido (9); Era un partido homenaje, se dijo, no una despedida. Porque nadie se atreve a matarle el 'sueño-jugador' a Maradona (11)".

Como observamos nos consensos, a transcendência de Maradona é uma dimensão dos jornalistas com muitos qualificativos, mas como os jornalistas também querem homenagear, persiste o dissenso sobre "como" ele vai transcender.

Para discutir as representações em nível de estereótipos de nacionalidade, associamo-las ao gaúcho argentino, que pertence à República Cisplatina. Após discussão e análise de textos fundadores da argentinidade, escolhemos o personagem Martín Fierro, de José Hernández, porque identificamos nele traços e valores positivos da identidade nacional. Esta associação justifica-se no sentido de que o gaúcho argentino e o modo como ele tem sido caracterizado e problematizado na literatura argentina, tanto pela via do ensaio quanto por um tratamento mais sociológico, permite discutir certos fundamentos da identidade nacional e parte significativa do que constitui a argentinidade. Essa condição permitiria explicar porque Maradona é popular, discutido e, mesmo, aceito.

Com o intuito de oferecer uma interpretação geral sobre as representações dos jornalistas sobre Maradona, vamos apresentálo como um gaúcho argentino típico. De fato, é o que ele, e como é representado em imagens e estátuas. Após levantamento e análise do modo como os jornalistas o retratam, cabe indagar: Quais as bases socioculturais que alimentam o conjunto de representações 
aqui evidenciadas? A alternativa de análise aqui seguida é a do imaginário do gaúcho cisplatino, o criollo ${ }^{6}$, fruto da miscigenação entre índios, nativos americanos ${ }^{7}$ e espanhóis.

As narrativas sobre a origem da consagração do gauchismo e da figura do gaucho como mito de raça e de argentinidade fundamse no imaginário cisplatino. O personagem principal da obra de Hernández, Martín Fierro, era pobre. Sua origem humilde fica particularmente retratada na estrofe 163: "Desde chiquito gané/ La vida con mi trabajo,/ Y aunque siempre estuve abajo/ Y no sé lo que es subir/ También el mucho sufrir/ Suele cansarnos, !barajo!".

Posteriormente, na estrofe 239, complementa a vida difícil: "Para él son los calabozos,/ Para él las duras prisiones,/ En su boca no hay razones/ Aunque la razón le sobre;/ Que son campanas de palo/ Las razones de los pobres".

Algumas representações consolidadas sobre Maradona podem se ancorar no personagem dessa lenda popular da literatura gaúcha de José Hernández. Rebeldia, transgressão, picardia, humildade de origem, habilidades (genialidades) e retornos se configuram e se combinam em pontos de convergência. No imaginário popular encontram relatos comuns aos protagonistas de ontem e de hoje, alguns reais, outros fictícios. No mundo da circulação dos relatos populares e da mídia, ambas as esferas podem acabar se fundindo, sendo abordadas no tratamento midiático e na opinião pública como se referindo ao mesmo protagonista.

\section{REPRESENTAÇÕES SOCIAS MIDIÁTICAS BRASILEIRAS SOBRE ROMÁRIO}

A seguir, analisamos as representações sociais dos jornalistas sobre Romário, em material publicado no dia seguinte ao jogo do Gol-mil e o aproximamos do mulato típico, descrito por Freyre em Sobrados e mucambos (1936).

${ }^{6}$ Criollo, cria da terra, remete a argentinidade.

${ }^{7}$ A estátua de Maradona, na entrada do Estádio do Boca Juniors, La Bombonera, retrata um índio prototípico, a ponto de os visitantes comentarem: não sabia que ele era índio. 
Começamos pelas categorias que representam consensos. As mais salientes destacam a origem humilde do herói, o volume de homenagens extracampo, sua posição de discípulo de Pelé, seu caráter polêmico, seu título de salvador da pátria, associado à conquista da copa do mundo de 1994, as homenagens intracampo e as dificuldades associadas ao homem comum, principalmente na figura relacionada ao papel de pai.

O primeiro consenso que se destaca nas narrativas é do herói, que no início de sua trajetória é descrito como pobre, favelado, faminto por gols. Na edição das representações sociais que depreendemos, Romário é apresentado pela imprensa como modelo de ascensão social, o que aumenta a identificação dos torcedores para com ele e para com os donos das empresas jornalísticas que, com esse recurso, esperam vender mais jornais. Conforme vários jornalistas destacaram naquele momento, Romário é parte de uma geração de jogadores de futebol de orientação crítica que, polemizando atrai a atenção para seus comentários e provocações. Numa época em que a polidez do discurso é um traço de consenso, ele ajuda os jornalistas esportivos na elaboração de suas pautas diárias. Editemos os jornalistas escrevendo sobre este aspecto da personalidade de Romário:

"driblou adversidades desde o berço, pediu que olhassem pelas crianças pobres do Brasil, uma delas era Romário, da infância invisível na favela para a galeria dos maiores de todos os tempos, seja para superar pobreza ou para surgir como um pequeno gigante entre os beques e fazer gols de cabeça do alto de seu $1,69 \mathrm{~m}$, o menino pobre entregava roupas lavadas pela mãe e carregava caminhões de melancia no subúrbio do Rio, nascido no Jacarezinho e criado na Vila da Penha, tinha em seu sangue suburbano o talento e a necessidade de oferecer dias melhores aos pais, teve uma época que seu pai teve que escolher entre seu irmão e ele para ir treinar, sabe o que é ser pobre, quase passou fome, não passou fome por pouco, faminto por gols, da Vila da Penha ao milésimo (Notícias: 14-18-34)". 
O aglomerado de fragmentos acima, resultado da nossa edição, descreve um homem singular, que fez o seu caminho com os próprios pés, literalmente. Abusca de falas consensuais sobre o herói mostrou presença expressiva de referências a frustrações, fracassos, preterições, além de lesões e contusões. Esta categoria refere-se aos contratempos decorrentes de eventos de natureza aleatória, que ele não pôde controlar, principalmente após seu desligamento da copa do mundo de 1998.

Pode-se interpretar, numa síntese das categorias de consenso, que o interesse por homenagear Romário, que se manifesta nas temáticas de dentro e de fora do campo esportivo, resultou num movimento de produção e interpretação de expectativa e ansiedade no contexto do futebol brasileiro. A edição das categorias qualifica Romário como personagem esportivo que as narrativas consagram e imortalizam.

Há dissenso na tese de que o herói já nasce feito e que está pronto para se esquivar, driblar os percalços da vida. Os treinos e toda a preparação para os jogos mostram que Romário não se encaixa na posição do jogador convencional. Há dissenso sobre se ele é o iluminado, o escolhido a partir do dom com que nasceu. Pergunta-se também até que ponto ele serve de exemplo para os demais que o seguem, repetindo uma trajetória já famosa no imaginário que relaciona pobreza e heróis do futebol.

Não há consenso sobre a contagem dos gols. Entre as entidades que contestam o alcance da meta se incluem a FIFA e a CBF, bem como alguns historiadores, pesquisadores e jornalistas:

\footnotetext{
"contagem cercada de polêmica, Romário chega aos mil gols marcado pela polêmica, desta maneira, Romário teria marcado ontem o gol de número 904, Romário admitiu que inclui os gols marcados antes da profissionalização e em jogos comemorativos, nunca disse que meus gols eram só de jogos oficiais e se fosse contar todos eles, teria quase três mi, craque inclui gols contestados, com ou sem mil gols (Notícias: 16-21-24)".
} 
Outro dissenso diz respeito ao balanço do gol mil, em termos de ganhos e perdas para o Vasco da Gama, que perdeu técnico e jogos, mas ganhou dinheiro e visibilidade:

"Para a paz pessoal de Romário e de sua família e até para a paz do Vasco, que sofria a ansiedade do Gol-Mil de Romário, tirou muito peso porque todos nós estávamos envolvidos nisso" (Notícias: 24-31). Confira-se, entretanto:

Com o projeto do gol mil, perderam três jogos e um técnico; o estádio lota com a sua presença...; Ele se emocionou e chorou mais uma vez, quando o time fez uma reunião para dizer a ele que não estava prejudicando o time.

Com base na análise das categorias, é possível constatar como o jornalismo carioca tem um discurso coletivo unânime, com poucos dissensos, sobre a imagem de Romário como mito esportivo contemporâneo. As críticas mais fortes e os poucos dissensos silenciaram após o Gol-mil.

Com o intuito de contribuir para a interpretação das representações acima expostas sobre Romário, identificamos algumas aproximações do nosso personagem com o mulato típico de Gilberto Freyre. Começamos esta aproximação com uma menção explícita à figura ao papel do mestiço:

O craque, de certa forma, encerra um ciclo de futebol-arte. A enganadora malemolência do seu futebol é a mesma que Gilberto Freyre identificava nos primeiros craques negros e mestiços nos idos dos anos 30. Eram tempos de Leônidas da Silva, Domingos da Guia e Fausto, 'A maravilha negra'. Romário faz parte dessa linhagem de monstros sagrados do futebol brasileiro. (SANTOS; MELO, 2007, p. 6).

Em Sobrados e mucambos, vários aspectos que Gilberto Freyre relata poderiam ser ilustrados pela trajetória de Romário. Para isso, precisamos descrever brevemente a obra o autor e o contexto no qual ela foi produzida. Freyre [1936] (1990) se preocupou em analisar a realidade psicossocial brasileira e em descrever a sua identidade. 
É a introdução à história da sociedade patriarcal no Brasil. Nesta sociedade, de origem judaico-cristã, se descreve como se produz a colonização e a escravidão e como a organização do autoritarismo e do poder de uns sobre outros contribuíram para formar a sociedade e a identidade do brasileiro.

$\mathrm{O}$ autor relata a trajetória gradativa da casa-grande e da senzala para o sistema habitacional de sobrados e mucambos. Após os engenhos das casas-grandes se desvalorizarem, as famílias se mudaram para os centros urbanos, onde tinham menos espaço para a construção do que na zona rural. Em parte por causa disso, a arquitetura edificou-se verticalmente, resultando no que foi chamado de sobrado. Por outro lado, após a abolição da escravidão, frente à decadência dos engenhos rurais, os ex-escravos foram procurar oportunidades perto do comercio urbano, organizaram sua moradia no que chamamos de mucambos, na periferia das cidades.

Nas relações entre sobrados e mucambos e entre o dominador, o dominado e a decadência do sistema patriarcal, Freyre descreve o que implica ser brasileiro, desde economia, vestimenta, alimentação, folclore, religião e as formas de lazer que ocupavam o tempo livre. Os jogos, a capoeira, a malandragem, a ginga, ele as considera características culturais, para explicar sua interpretação da brasilidade.

Esses detalhes da obra ajudam a compreender a formação da cultura brasileira e a miscigenação entre as raças. O autor argumenta que a miscigenação entre os europeus, os negros e os nativos do Brasil, então considerada como o grande problema nacional, se apresenta como a solução do Brasil e afirma que, por meio do branqueamento da raça e da miscigenação, se produz o "mito da democracia racial".

Com base no que acabamos de apresentar, postulamos Romário como candidato a brasileiro-síntese de Sobrados e mucambos, que inverteu a tendência apresentada por Freyre. Efetivamente, partindo de uma origem humilde e sem poder, após a sua ascensão como jogador de futebol, por meio do seu desempenho genial, passou do 
mucambo ao sobrado. Utilizou a ginga, a capoeira e as práticas de malandragem como recursos ressignificados para essa ascensão social. Para interpretar as características de Romário, como homem que passou do mucambo ao sobrado, comparamos o papel da mãe, descrita em Sobrados e mucambos, com o papel da mãe de Romário, como formadora do herói vitorioso.

A mãe de Romário pode ser interpretada como representante "da mulher estável e mãe de família em nossa formação. Sem essa figura quase matriarcal de mulher-matrix, não se imagina a casagrande de engenho, que foi o centro da nossa integração social" (FREYRE, 1990, p. 32). Na análise da formação de Romário, observamos a inclusão da cultura africana dentro da cultura brasileira, sobretudo pela influência da mãe, representante das mulatas que passam as culturas africanas, ensinando as crianças brancas a falar e repassam contos, cantos e tradições dessas culturas. Também observamos a transmissão cultural através de cozinheiras que introduzem seus temperos africanos nas receitas francesas. Essas mulheres perpetuam a cultura africana por meio de religião, crenças, enfeites, vestimentas, lendas e valores. A mãe de Romário comunga, com as mães de brasileiros ilustres, de origem humilde ou africana, o mérito de aristocratizar seus filhos, oportunizando seu contato com saberes técnicos. No caso de Romário, a técnica elucida-se nas genialidades corporais brasileiras, que ele soube criar e utilizar no futebol.

Romário é o mulato típico, que é bem sucedido. O primeiro aspecto diz respeito à ascensão social, do mucambo para o sobrado. A mobilidade social do mulato pobre, de origem humilde, do mucambo, consegue ascender de status e passar a uma melhor vida no sobrado. Tal ascensão prevista aconteceu com brasileiros (mulatos) que se destacavam em suas profissões, como jornalistas, médicos, escritores, políticos, advogados e esportistas. Segundo Freyre, com a urbanização do país, alterou-se o equilíbrio entre brancos e pretos, caboclos e pardos livres de mucambos, pois "tornavam-se maiores as oportunidades de ascensão social, nas cidades, para os escravos e para os filhos dos escravos, que fossem indivíduos dotados de 
aptidão artística ou intelectual extraordinária ou de qualidades especiais de atração sexual" (FREYRE, 1990, p. 153). No sentido da ascensão social ou branqueamento da raça, Romário entra na lista de "alguns dos nossos mulatos mais notáveis que, pela ascensão econômica ou intelectual, tornaram-se oficialmente brancos" (FREYRE, 1990, p. 643).

Podemos relacionar a inteligência corporal de Romário a algumas capacidades de brasileiros descritas por Freyre (1990, p. 648), como "à capacidade para a análise sociológica [...] revelada por outros negróides de alta inteligência em nosso país." Ao analisar os primeiros relatórios do tempo do Império, o autor mostra resultados de estudos de alguns mestres da época. Esses relatórios indicam o aproveitamento dos alunos classificados pela cor, onde as evidências não comprovaram inferioridade do mestiço "- que seria tanto o mulato como o cafuzo e o curiboca, mas particularmente o mulato -, mas de sua aptidão para os estudos' (FREYRE, 1990, p. 648). Romário se enquadra nos termos de Freyre, para quem a ascensão de mulatos se realizava não só do mais claro quanto do mais obscuro - como "os atletas, os nadadores e os jogadores de foot-ball" (FREYRE, 1990, p. 649), que são quase todos mestiços.

Com respeito ao mito da "democracia racial", Freyre assevera que em nenhum país da extensão do Brasil existe tanta mobilidade social, tanto vertical como horizontal, tantas facilidades de ascensão social e política: "talvez em nenhum outro país seja possível ascensão social mais rápida de uma classe a outra: do mucambo ao sobrado. De uma raça a outra: de negro a 'branco', ou a 'moreno' ou 'caboclo'" (FREYRE, 1990, p. 654).

O segundo aspecto diz respeito à causa da ascensão: desempenho e genialidade corporal. Com efeito, o traço que fez o esportista Romário ascender ao sobrado foi a genialidade corporal, o desempenho. Falando das características do Brasil, em comparação com outros países, podemos relacionar Romário como protótipo de brasileiro; para Freyre, o Brasil nunca será como Argentina, quase europeia, ou o Paraguai e o México, predominantemente ameríndios. 
Assim, "a substância da cultura africana permanecerá em nós através de toda a nossa formação e conformação de nação" (FREYRE, 1990, p. 650).

No processo da miscigenação, os mulatos tiveram a habilidade de incorporar os ganhos da ginga, da capoeira e da malandragem, e ressignificá-la, ressemantizá-la como substância propriamente brasileira. Romário representa a perfeição da ascensão pelo desempenho corporal e nesse aspecto particular confirma a trajetória de mucambo a sobrado.

Com relação aos mulatos que passaram dos mucambos para sobrados por meio da genialidade e do talento, Freyre cita Correia de Azevedo, que considerava que, para o país crescer, dependia da participação do "'povo, esse sangue ardente das grandes artérias de trabalho'; povo do qual teria que sair 'todo o talento patriótico de construir um grande e abençoado país" (FREYRE, 1990, p. 182).

No processo de transição, "o patriarcalismo brasileiro, vindo dos engenhos para os sobrados, não se entregou logo à rua; por muito tempo (esses espaços) foram quase inimigos." (FREYRE, 1990, p. 39). Mas Romário ressignificou essa rua com valores positivos, que lhe permitiram aprender a ginga e a malandragem de gênio, para sobreviver e ascender.

Falando sobre alguns escravos que inicialmente viviam com as famílias rurais que se mudavam para a cidade, Freyre destaca que eles portavam características que os diferenciavam como marca registrada, quando eram crias da casa-grande ou do sobrado: eram conhecidos pelo jeito de falar arrastado, semelhante ao jeito de andar do malandro. Após a abolição, "Muito ex-escravo, assim degradado pela liberdade e pelas condições de vida no meio urbano, tornou-se malandro de cais, capoeirista, ladrão, prostituta e até assassino. $\mathrm{O}$ terror da burguesia dos sobrados" (FREYRE, 1990, p. 179). Em nossa investigação, constatamos que o discurso jornalístico tende a adotar essa malemolência, essa ginga, essa malandragem, pertencentes ao comportamento de Romário, dentro e fora de campo. 
A rua era considerada uma influência negativa para as crianças, a tal ponto que "Menino de sobrado que brincasse na rua corria risco de degradar-se em moleque" (FREYRE, 1990, p. 152), e sinhazinha que fosse sozinha para a rua poderia ser considerada mulher pública. No caso de Romário, ele aproveitou a escola da sobrevivência na rua, jogando peladas de várzea e graduou-se, positivamente, como moleque.

O terceiro aspecto se refere ao novo status, de novo rico, e aos modos cordiais de assobradado. Romário virou novo rico, adquiriu modos cordiais, de etiqueta, ficou cordial; seu humor é irônico, ele é cortês, fino e simpático. Assumiu, assim, a fala e o lugar do mulato cordial, equilibrado, comedido e civilizado, que é brincalhão, feliz, faz muitas piadas e está sempre alegre. Algumas características com que Freyre descreve Nilo Peçanha, por exemplo, se ajustam a Romário, como arrivismo de novo-poderoso e simpatia característica do mulato brasileiro, quando está determinado ao sucesso (FREYRE, 1990, p. 643). Podemos ver alguns aspectos de Romário na simpatia do brasileiro, que é "evidentemente maior no mulato" do que na raça ariana (FREYRE, 1990, p. 643).

A auto-estima também merece um breve comentário. Após ter conquistado status elevado, Romário nos permite entrever como esses mulatos se sentiam: "Alguns deles - mulatos triunfantes - no meado do século XIX, já se sentiam mais 'celtas' ou mais europeus na aparência - e não apenas na cultura de bacharéis ou doutores do que brancos há longo tempo fixados no Brasil" (FREYRE, 1990, p. 645).

Freyre consagra a ideia da miscigenação que deu certo, abrindo possibilidades para a mobilidade social. "Essas qualidades e esses recursos plásticos de mulato em ascensão para branco, e de filho ou neto de escravo, em ascensão para senhor, encarnou-as Nilo Peçanha do modo mais expressivo. Quase ninguém se lembra de o ter visto senão sorrindo ou então rindo, os dentes cordialmente de fora." (FREYRE, 1990, p. 646). 
Essa cordialidade vai mais além do uso de diminutivos: "outra expressão reveladora do arrivismo social do mulato é a utilização de termos eruditos e palavras solenes" (FREYRE, 1990, p. 647), o que Romário transforma em frases irônicas, criativas, engraçadas e polêmicas que, por vezes, ferem as regras da cordialidade.

No quarto aspecto, contemplamos as exigências do novo status: aceitar novos modos sem esquecer as origens. Logo após ter subido ao sobrado, ter se civilizado e desbarbarizado, ele não fica preso a seu novo status. Ele volta às origens, confirmando a tese do mulato típico.

Cabe ponderar que Romário representa o bom jogador, mas é um personagem contraditório. Segundo estrangeiros que visitavam o país, na tentativa das elites brasileiras se diferenciarem da plebe, um dos grandes sinais de fidalguice era quase não sair, e ser visto o menos possível na rua, para não ser confundidos com aquela parte da população que os grandes chamam de povo (FREYRE, 1990, p. 39). Neste quesito, Romário se afasta um pouco da previsão do autor, pois passou do mucambo ao sobrado por meio dos ensinamentos da rua, tornou-se fidalgo, mas sempre volta às suas origens, pois, embora não beba, aceita ser visto na rua e na noite, com o povo.

Por fim, registramos as polêmicas e tensões por superexposição e popularidade. Para Freyre, a realidade brasileira mostra vestígios da experiência escravocrata, processo recorrente, que durou séculos; os efeitos podem ter variado de acordo com cada sociedade ou realidade regional, de acordo com o efeito de seu impacto, face às resistências psicossociais ou psicoculturais. Mesmo que se encontrem vestígios psicossociais, psicoculturais e psicoeconômicos nas experiências com os descendentes desses escravos, alguns efeitos dessa resistência podem ter transformado alguns desses efeitos negativos em benéficos, como observamos no caso de Romário. $\mathrm{O}$ fato de ser novo rico permitiu-lhe criar polêmicas e tensões com os que estão contra ele ou contra os contra aqueles dos quais ele acredita que se deve defender e, principalmente, por aceitar ser visto na rua e na noite. A opção por ser visto assim e observado pela 
superexposição midiática gera a tensão da corda esticada. Qualquer erro ou afastamento do que é considerado ético, moral ou normal se divulga e interpreta criticamente.

Em síntese, consideramos Romário como o mulato que deu certo, com base nos traços brasileiros que identificamos: passou do mucambo ao sobrado, por meio de suas condições e capacidades geniais, adquiriu novos modos, reconhece sua origem humilde, mas convive com certa tensão nessa situação de poder do novo rico. É cordial, afável, respeita a família é ídolo nacional.

\section{ConClusões}

Nas representações sociais de Maradona há uma aproximação ao personagem Martín Fierro quanto às características de: Humildade de origem, Rebeldia/transgressão, Genialidade e Retornos. É um exemplo argentino, o que evidenciamos por meio de indícios (GINZBURG, 1989) que se confirmam nas representações de Propriedade do povo, Idolatria-reconhecimento, Religiosidade, Eternidade-imortalidade e Lenda-mitificação. Como Martín Fierro, é um mito gaúcho humilde de origem, rebelde, transgressor, genial, fadado ao retorno e religioso. Cabe aprofundar o estudo, para verificar até que ponto as características analisadas se mantêm para o homem urbano.

Nas representações sociais dos jornalistas sobre Romário destaca-se uma aproximação ao mulato típico descrito em Sobrados e Mucambos quanto a: humildade de origem, rebeldia, transgressão, ascensão social do mucambo para o sobrado por meio da genialidade, aquisição de modos cordiais de novo rico assobradado e aceitação dos novos modos, sem esquecer as origens. Por último, destacamse as polêmicas e tensões associadas a superexposição e popularidade. Personagem construído na base da miscigenação entre as raças, Romário é detentor de indícios fortes (GINZBURG, 1989) da herança da cultura africana e da dimensão da religiosidade. Em novos estudos, cabe verificar, no imaginário popular, o grau de consenso dessas representações que circulam na mídia jornalística. 
Pode-se concluir que Maradona e Romário convergem nas representações sociais nas dimensões analisadas, por se aproximarem das suas origens, manterem seus vínculos primários e fundarem seus projetos de ascensão social pelo futebol. Concluímos também que Maradona e Romário se afastam no que se refere ao vínculo com o torcedor e à transcendência. $\mathrm{O}$ vínculo com o torcedor se deve à aceitação do personagem pelos valores de sua cultura, principalmente a transgressão e malandragem que, na Argentina se interpreta como o "mito da picardia" do Martín Fierro e de argentinidade (HERNÁNDEZ, [1872] 1962a - [1879] 1962b). No Brasil, cabe verificar até que ponto tal picardia se aceita da "boca para dentro", testando a proporção que tal picardia se assume publicamente, ou fica apenas em acordo de falas na "cozinha da casa grande" (FREYRE, 2003). Quanto à transcendência, cabe verificar também se de fato o imaginário argentino teria uma ligação forte da religião com o futebol (RECASENS SALVO, 2005), enquanto o Brasil possuiria um imaginário mais monárquico e o futebol mais afastado do sagrado (HELAL; GORDON JUNIOR, 2001).

O estudo conduzido até agora indica que existem mais consensos nos jornalistas argentinos com respeito às representações sociais sobre Maradona e mais dissensos nos jornalistas brasileiros com respeito às representações sociais sobre Romário. Maradona representaria o típico gaúcho criollo argentino na perspectiva de Jose Hernández, enquanto Romário representaria o mulato típico brasileiro na perspectiva de Gilberto Freyre. Ambos sobrevivem e triunfam por causa da genialidade e do desempenho atlético, mostrando pela via do futebol um espaço próprio de circulação da tradição dos dois povos. Novos estudos permitiriam averiguar o papel dos dois textos fundadores aqui acolhidos como definidores das duas culturas.

Por fim, pesquisas futuras podem trazer outros pontos de análise entre a cultura esportiva desses dois países, quer no futebol, quer em outros esportes, com análise de trajetórias de seus expoentes no esporte. 
Social Representations of Argentinian and Brazilian Journalists about Maradona and Romário

Abstract: This paper analyzes social representations of Argentinian and Brazilian journalists about Maradona and Romário, in printed press, delivered after the game in honor of the first and after the goal number one thousand, of the second. The Argentinian corpus of analysis is compound by 12 reports, from different newspapers. The Brazilian one has 34 reports. The analysis of these reports resulted in the five following consensual categories, related to both athletes: social origin, professional performance, personal features, interaction with fans and transcendence. The non consensual categories refer to specific facts in the carrier of every athlete. The content analysis of social representations related to Maradona favors associating him with the Argentinian gaucho Martín Fierro. In what concerns Romário, he represents the Freyrian mulato, who ascends from mucambo to sobrado.

Key-words: Social representations. Consensual categories. Non consensual categories. Printed media.

\section{Representaciones sociales de periodistas argentinos y brasileros sobre Maradona y Romário}

Resumen: Este artículo analiza representaciones sociales de periodistas argentinos y brasileros sobre Maradona y Romário, en noticias publicadas después el partido homenaje del primero, y después del milésimo gol del segundo. El corpus argentino de análisis se conforma por 12 noticias de diferentes diarios impresos. El brasilero, de 34 noticias. El análisis de las noticias resultó en cinco categorías de consenso sobre ambos homenajeados: origen social, desempeño profesional, características personales, vínculo con los hinchas y trascendencia. Los disensos están asociados a hechos puntuales, en la carrera de cada uno de los atletas. El análisis de contenido de las representaciones sobre Maradona permite asociarlo al gaucho argentino Martín Fierro. En cuanto a Romário, sobresale el mulato de Gilberto Freyre, que pasa del mucambo para el sobrado.

Palabras-clave: Representaciones sociales. Consensos. Disensos, Prensa gráfica. 
Representações sociais de jornalistas argentinos e...

Lista de notícias sobre o jogo-homenagem de Maradona (10/11/2001)

1. BARONE, O. Enigmas de un oráculo descotrolado. La Nación , Bs. As., 11 nov. 2001, p. 4.

2. BILARDO, C. S. El futuro sólo depende de él. Que la fiesta dure... Puntal, Río Cuarto (Córdoba), 13 nov. 2001, p. 6.

3. DANISHEWSKY, S. ¿Quién es el dueño de Diego? Clarín, Bs. As., 12 nov. 2001, p. 32.

4. FARINELLA, L. Maradona es de todos: Gracias Diego. Olé, Bs. As., 11 nov. 2001, p. 19.

5. GROSSO, C. El mito y los hinchas (La fiesta). La Nación , Bs. As., 11 nov. 2001, p. 6-7.

6. LLONTO, P. Reír y llorar, ésa es la vida: Diego vivió uno de los días de mayor impacto en su vida. Pero más allá de sus fiestas, la de la cancha y la del hotel, aquí están algunas de las historias que lo rodearon y lo conmovieron. El Gráfico, Bs. As., 13 nov. 2001, p. 28-34.

7. MALADESKY, A. Y fue el día 10. Maradona vivió una fiesta de homenaje inolvidable. Diego jugó todo el partido para la Selección de Bielsa, aunque con algunas sorpresas... Lloró Diego y lloramos todos. Olé, Bs. As., 11 nov. 2001, p. 3.

8. MARINI, J. El homenaje. El nunca se irá. No hay modo de que Maradona sea un ex jugador. El futbolista más grande conoce la dureza de la vida y fue objeto de una voluntad repetida de uso político. Pero su lazo con la gente se sostiene en un sentimiento extraordinario, es amor. Clarín, Bs. As., 11 nov. 2001, p. 16.

9. MAURI, C. Una carrera única. Un sentimiento. Las más nobles emociones en el agasajo a Maradona. La Nación , Bs. As., 11 nov. 2001, p. 2.

10. MORALES, V. H. Gracias maestro. Puntal, Río Cuarto (Córdoba), 11 nov. 2001, p. 7.

11. PAGANI, H. La fiesta 10. Clarín, Bs. As., 11 nov. 2001, p. 3-4.

12. VERONA, E. (Notas de CEDEIRA, R.; NÓBILI, M.; ARO GERALDES, P.; e ROSE, M. de) El Diez, el Dios: el fútbol argentino le regaló a Diego Armando Maradona el homenaje que se merecía. El Gráfico, Bs. As., 13 nov. 2001, p. 18-26.

Lista de notícias publicadas sobre o Jogo-Gol-Mil (21/05/2007)

1. EQUIPE EDITORIAL. Companheiros comemoram o feito. Extra, Rio de Janeiro, 21 de maio, 2007, p. 6.

2. ARRUDA, R. Extra. O rei aplaude o pupilo. Extra, Rio de Janeiro, 21 de maio, 2007, p. 4. 


\section{ArtigosOriginais}

3. Equipe Editorial. Romário marca o milésimo e a pedido do Extra escreve a manchete: eu sou o cara! Extra, Rio de Janeiro, 21 de maio, 2007, p. 1.

4. AÍDA, D. A coroação de um imortal. Extra, Rio de Janeiro, 21 de maio, 2007, p. 3.

5. LEITE, E. Mil vezes Romário. Extra, Coluna, Rio de Janeiro, 21 de maio, 2007, p. 2.

6. Equipe Editorial. O inferno astral no Fla. Extra, Edição Especial: Romário 1000 gols, Rio de Janeiro, 21 de maio, 2007, p. 8.

7. Equipe Editorial. O Brasil inteiro pede por Romário. Extra, Edição Especial: Romário 1000 gols, Rio de Janeiro, 21 de maio, 2007, p. 11.

8. Equipe Editorial. De novo o Rei de São Januário. Extra, Edição Especial: Romário 1000 gols, Rio de Janeiro, 21 de maio, 2007, p. 10.

9. Equipe Editorial. O choro do artilheiro. Extra, Edição Especial: Romário 1000 gols, Rio de Janeiro, 21 de maio, 2007, p. 9.

10. Equipe Editorial. O mundo aos pés do baixinho. Extra, Edição Especial: Romário 1000 gols, Rio de Janeiro, 21 de maio, 2007, p. 7.

11. Equipe Editorial. Na Europa, brilho e frustração. Extra, Edição Especial: Romário 1000 gols, Rio de Janeiro, 21 de maio, 2007, p. 5.

12. Equipe Editorial. Descoberta e início promissor. Extra, Edição Especial: Romário 1000 gols, Rio de Janeiro, 21 de maio, 2007, p. 3.

13. Equipe Editorial. Roth: 'Foi uma honra receber o abraço dele'. Extra, Rio de Janeiro, 21 de maio, 2007, pp. 8 e 9.

14. Equipe Editorial. O parceiro da camisa 11. Extra, Edição Especial: Romário 1000 gols, Rio de Janeiro, 21 de maio, 2007, p. 4.

15. Equipe Editorial. O rei da noite e da grande área. Extra. Edição Especial: Romário 1000 gols. Rio de Janeiro, 21 de maio, 2007, p. 6.

16. Equipe Editorial. Corrida final pelo milésimo gol. Extra. Edição Especial: Romário 1000 gols. Rio de Janeiro, 21 de maio, 2007, p. 12.

17. Equipe Editorial. Magrão faz apelo mas não evita o papel de vítima. O Globo. Rio de Janeiro, 21 de maio, 2007, p. 3.

18. Pedro M. G. Um craque genial movido a gols e desafios. O Globo. Rio de Janeiro, 21 de maio, 2007, p. 5.

19. Equipe Editorial. Gol mil antes dos 30. O Globo. Rio de Janeiro, 21 de maio, 2007, p. 5. 
20. Equipe Editorial. Angustia do gol mil acaba em São Januário. O Globo. Rio de Janeiro, 21 de maio, 2007, p. 4.

21. Equipe Editorial. Contagem cercada de polêmica. O Globo. Rio de Janeiro, 21 de maio, 2007, p. 3.

22. ARRUDA, R. Pelé elogia Romário e diz que o artilheiro foi um bom aluno. O Globo. Rio de Janeiro, 21 de maio, 2007, p. 2.

23. Equipe Editorial. 999 gols na cabeça e o milésimo repetindo Pelé. O Globo. Rio de Janeiro, 21 de maio, 2007, p. 3.

24. CALAZANS, F. O dono da obra. O Globo. Rio de Janeiro, 21 de maio, 2007, p. 2.

25. GERHEIM, J. A. Romário faz história. Jornal dos Sports. Rio de Janeiro, 21 de maio, 2007, p. 3.

26. SANTOS, D e MELO, S. A apoteose do artilheiro. Jornal dos Sports. Rio de Janeiro, 21 de maio, 2007, p. 4.

27. SANTOS, D. e MELO, S. O choro do reconhecimento. Jornal dos Sports. Rio de Janeiro, 21 de maio, 2007, p. 5.

28. SANTOS. D. e MELO, S. Eterno Romário. Jornal dos Sports. Rio de Janeiro, 21 de maio, 2007, p. 6.

29. SANTOS. D. e MELO, S. Os incríveis números de um goleador. Jornal dos Sports. Rio de Janeiro, 21 de maio, 2007, p. 7.

30. TIRONI, E. Explosão de alegria na redação. O Lance. Rio de Janeiro, 21 de maio, 2007, p. 3.

31. Equipe Editorial. Depois do mil, talvez o México. O Lance. Rio de Janeiro, 21 de maio, 2007, p. 22.

32. DANTAS, R. 'Tarde de gala no Maracanã'. Mil vezes Romário: Jogo inesquecível. Lance ativo. O Lance. Rio de Janeiro, 21 de maio, 2007, p. 26.

33. GARCEZ, J. 'Despedida emocionante'. Mil vezes Romário: Jogo inesquecível. Lance ativo. O Lance. Rio de Janeiro, 21 de maio, 2007, p. 21.

34. TORRE, P. H. Da Vila da Penha ao milésimo. Mil vezes Romário. Lance ativo. O Lance. Rio de Janeiro, 21 de maio, 2007, p. 21. 


\section{REFERÊNCIAS}

ARCHETTI, E. P. Masculinidades: fútbol, tango y polo en la Argentina. Buenos Aires: Antropofagia, 2003a.

ARCHETTI, E. P. El potrero y el pibe. Territorio y pertenencia en el imaginario del fútbol argentino. Porto Alegre: Horizontes Antropológicos - Vol.14 n 30, Jul/Dec 2008.

BARCELONA, E. M. Imágenes de los ídolos. Aportes del interaccionismo de Goffman para el análisis de personajes. Lecturas: Educación Física y Deportes. Disponível em: <www.efdeportes.com>. Revista Digital-Buenos Aires. ISSN 15143465. Año 9-N66-, 2003.

"El Diego de la gente": convergências e divergências entre as imagens da mídia impressa e sua autobiografia. Dissertação. (Mestrado em Ciência do Movimento Humano) - Centro de Educação Física e Desportos, Universidade Federal de Santa Maria, Santa Maria, 2004.

Convergências e divergências entre as imagens de Maradona da mídia argentina e sua autobiografia. In: SANFELICE, Gustavo Roese; MYSKIW, Mauro (Org.). Mídia e esporte: temas contemporâneos. Novo Hamburgo: FEEVALE, 2010a. p. 122-141.

Representações sociais da mídia argentina e brasileira sobre Maradona e Romário. 2010b. Tese (Doutorado em Educação Física) - Faculdade de Educação Física, Universidade de Gama Filho, Rio de Janeiro, 2010 b.

BARDIN, L. Análise de conteúdo. Portugal: Edições 70, 2009.

DINI, V.; NICOLAUS, O. Te Diegum Maradona: genio y transgresión. Buenos Aires: Sudamericana, 2001.

ELIAS, N; DUNNING, E. A busca da excitação. Lisboa: DIFEL, 1992.

FARINELLA, L. Diez es argentino. Olé, Buenos Aires, 2008;

FREYRE, Gilberto. Casa Grande \& Senzala: formação da família brasileira sob o regime da economia patriarcal. 48ํe. São Paulo: Global, [1933] 2003.

Sobrados e mucambos. Rio de Janeiro: 8o ed. Record, [1936] 1990.

GALEANO, E. El futbol a sol y sombra y otros escritos. Córdoba: Ediciones P/ L@, 2002.

GINZBURG, C. Mitos, emblemas, sinais: morfologia e história. São Paulo: Companhia das Letras, 1989.

Movimento, Porto Alegre, v. 18, n. 02, p. 205-233, abr/jun de 2012. 
HELAL, R.; GORDON JUNIOR, C. A pátria de chuteiras e a identidade nacional. In: VOTRE, Sebastião. (Org.). Imaginário e representações sociais em educação física, esporte e lazer. Rio de Janeiro: Editora Gama Filho, 2001. p. 147-162.

HERNÁNDEZ, J. Martín Fierro. Buenos Aires: EUDEBA, [1872]1962a.

La vuelta de Martín Fierro. Buenos Aires: EUDEBA, [1879] $1962 b$.

JOGO EXTRA. Reencontro no domingo: hermanos pegam o México nas oitavas, como em 2006, mas agora com Messi como titular. Rio de Janeiro, 23 junio. 2010, p. 12.

LEFEBVRE, F.; LEFEBVRE, A. M. C. Depoimentos e discursos: uma proposta de análise em pesquisa social. Brasília: Líber Livro, 2007.

LOVISOLO, H. Vizinhos distantes: universidade e ciência na Argentina e no Brasil. Rio de Janeiro: EdUERJ, 2000.

MOSCOVICI, S. A representação social da psicanálise. Rio de Janeiro: Zahar, 1978.

PICABEA, M. L. Uno de los fenómenos editoriales del año: Diego ahora hace jueguito con los libros y es best seller global, Con goles y frases de Maradona se armaron algunos de los libros más vendidos. Clarín, Buenos Aires, 30 de dez. 1995. Disponível em: <http://www.clarin.com/diario/2005/12/30/sociedad/s-05701.htm>. Acesso em: 09 jan. 2007.

RECASENS SALVO, A. EI Deportivo Laferrere: un acercamiento antropológico al fenómeno del fútbol y sus vínculos con la religión. Universidad de chile. Facultad de ciencias sociales. Departamento de antropología. Tesis para optar al título profesional de antropólogo social. Américo provoste Valderrama. Santiago de Chile 2005. Disponível em: <http://www.cybertesis.cl/tesis/uchile/2005/provoste_a/ sources/provoste_a.pdf>. Acesso em: 10 jan. 2011.

SANTOS. D.; MELO, S. Eterno Romário. Jornal dos Sports, Rio de Janeiro, p. 6, 21 maio 2007.

Endereço para correspondência:

Rua Presidente João Pessoa, 153/1102. Icaraí.

Niterói/RJ.

CEP: 24240-460. 
